\title{
Nordvestfjord: a major East Greenland fjord system
}

\author{
J. A. DOWDESWELL ${ }^{1 *}$, C. L. BATCHELOR ${ }^{1}$, K. A. HOGAN ${ }^{1} \&$ H.-W. SCHENKE ${ }^{2}$ \\ ${ }^{1}$ Scott Polar Research Institute, University of Cambridge, Cambridge CB2 1ER, UK \\ ${ }^{2}$ Alfred Wegener Institute for Polar and Marine Research, 27515 Bremerhaven, Germany
}

*Corresponding author (e-mail:jd16@,cam.ac.uk)

\begin{abstract}
Fjords are deep valleys that have been flooded by encroaching sea water after ice retreat (Syvitski et al. 1987). They are produced mainly by glacial erosion, with the ice sometimes exploiting pre-existing river systems or structural weaknesses. Fjords are found in mountainous terrain in all areas affected by large glaciers and ice sheets, both today and during full-glacial periods. They are, therefore, a distinctive landform indicative of past glacial activity.
\end{abstract}

\section{Description}

Nordvestfjord is a $140 \mathrm{~km}$-long fjord that is typically about $5 \mathrm{~km}$ wide with very steep walls (Fig. 1a-g). The mountains surrounding Nordvestfjord rise to over $2,000 \mathrm{~m}$. Several small branches join the fjord before it enters the much wider and shallower Hall Bredning, part of the Scoresby Sund fjord system in East Greenland (Fig. 1b) (Dowdeswell et al. 1994). From the head of the fjord to the outer coast of Greenland is about $300 \mathrm{~km}$ (Fig. 1b), making Scoresby Sund the largest fjord system in the world at $13,700 \mathrm{~km}^{2}$. The whole fjord system was occupied by ice during the Last Glacial Maximum (Dowdeswell et al. 1994). Deglaciation of Scoresby Sund began about 16,000 years ago. Ice probably retreated to Milne Land, at the mouth of Nordvestford, by about 10,000 years ago, but retreat through Nordvestfjord itself was late, perhaps not taking place until 6-7,000 years ago (Funder et al. 1998).

Near its head, Nordvestfjord bifurcates, and several major outlet glaciers of the Greenland Ice Sheet have their marine margins here (Fig. 1a). The largest of these is Daugaard Jensen Gletscher, which drains an area of $50,000 \mathrm{~km}^{2}$ back to the crest of the ice sheet. The marginal few kilometres of Daugaard Jensen Gletscher have a very low ice-surface profile, suggesting that it is afloat (Fig. 1f). Mass is therefore lost from the glacier by both iceberg production and undermelting of its floating tongue; ice flux at the grounding-line of Daugaard Jensen Gletscher is estimated at about $10 \mathrm{~km}^{3} \mathrm{a}^{-1}$ (Enderlin \& Howat 2013)

The bathymetry of Nordvestfjord has a series of basins, up to 1,400 m deep and typically in excess of 1,000 m (Fig. 1a, c). The basins are separated by several bedrock sills of $600-900 \mathrm{~m}$ in depth. The fjord floor shallows to about $400 \mathrm{~m}$ as it opens eastward into the wider Hall Bredning. Fjord walls are characteristically steep both below (Fig. 1d) and above the waterline (Fig. 1g), although there are a few places where side valleys with proglacial rivers drain into the fjord (Fig. 1a). The cross-profile of the fjord has a U-shape (Fig. 1d, g).

The seafloor of Nordvestfjord is smooth and relatively regular in the deep basins (Fig. 1a, c). Shallow sub-bottom profiles show that basins are filled with sediments which are typically laminated acoustically (Fig. 1e) (Ó Cofaigh et al. 2001). Penetration can exceed $100 \mathrm{~m}$, indicating that the sediments are fine-grained. The sills between these basins have steep slopes and a thin veneer of sediment sometimes overlies bedrock, through which the acoustic signal does not penetrate. There is some evidence of mass transport down the flanks of these inter-basin sills in acoustic records (Fig. 1e).

In innermost Nordvestfjord, within about $20 \mathrm{~km}$ of the modern termini of Daugaard Jensen and Graae glaciers (Fig. 1a), the otherwise relatively smooth sediments of the fjord floor are dissected by sinuous channels (Fig. 1c, f). Channels from the two innermost branches of the fjord join to form a single sinuous trunk channel, which meanders over the flat seafloor for a further $10 \mathrm{~km}$ until losing its form in a deep basin. Fjord floor channel width is between 100 and $400 \mathrm{~m}$, and depths range from 5 to $50 \mathrm{~m}$; channel length is about $30 \mathrm{~km}$ (Fig. 1f).

\section{Interpretation}

Nordvestfjord is interpreted to be a classical example of a steep-walled and U-shaped fjord eroded by predominantly glacial action during late Cenozoic glaciations. In addition, ice-sheet drainage in Greenland during the early phases of glaciation may have been influenced by a pre-glacial fluvial landscape; there is some evidence of pre-glacial fluvial sediments beneath glacial debris in the major fan-system offshore of Scoresby Sund (Dowdeswell et al. 1997). In addition, the overall position of the fjord probably influenced by older geological structures. The more detailed morphology of the fjord, specifically its set of overdeepened basins in long-profile (Fig. 1c), and its steep-sided, U-shaped cross-profile (Fig. 1d, g), are also a product of glacial erosion (Harbor 1992).

Sediments on the fjord floor are probably derived from three main processes (Ó Cofaigh et al. 2001): sediment-gravity flows, in the form of turbidity currents, as demonstrated by the presence of sinuous submarine channels (Fig. 1f), and debris flows on steeper slopes; suspension-settling from turbid meltwater; and rafting from icebergs traversing the fjord. These processes have contributed to Holocene basin-fill after a late deglaciation.

\section{References}

DOWDESWELL, J. A., UENZELMANN-NEBEN, G., WHITTINGTON, R. J. \& MARIENFELD, P. 1994. The Late Quaternary sedimentary record in Scoresby Sund, East Greenland. Boreas, 23, 294-311. 


\section{J.A. DOWDESWELL ET AL.}

DOWDESWELL, J. A., KENYON, N. H. \& LABERG, J. S. 1997. The glacier-influenced Scoresby Sund Fan, East Greenland: evidence from GLORIA and $3.5 \mathrm{kHz}$ records. Marine Geology, 143, 207-221.

ENDERLIN, E. M. \& HOWAT, I. M. 2013. Submarine melt rate estimates for floating termini of Greenland outlet glaciers (20002010). Journal of Glaciology, 59, 67-75.

FUNDER, S., HJORT, C., LANDVIK, J. Y., NAM, S.-I., REEH, N. \& STEIN, R., 1998. History of a stable ice margin - East Greenland during the middle and upper Pleistocene. Quaternary Science Reviews, 17, 77-123.

HARBOR, J. M. 1992. Numerical modelling of the development of U-shaped valleys by glacial erosion. Bulletin Geological Society of America, 104, 1364-1375.

Ó COFAIGH, C., DOWDESWELL, J. A. \& GROBE, H. 2001. Holocene glacimarine sedimentation, inner Scoresby Sund, East Greenland: the influence of fast-flowing ice-sheet outlet glaciers. Marine Geology, 175, 103-129.

SYVITSKI, J. P. M., BURRELL, D. C. \& SKEI, J. M. 1987. Fjords: Processes and Products. Springer, Berlin, 379 pp.

Fig. 1. Nordvestfjord, East Greenland. (a) Swath bathymetry of Nordvestfjord superimposed on Landsat imagery of the area. Acquisition system Atlas Hydrosweep DS-1. Frequency15 kHz. Grid-cell size $30 \mathrm{~m}$. DJG is Daugaard Jensen glacier, GG is Graae glacier. (b) Location of study area (red box; map from IBCAO Version 3.0). The location of Scoresby Sund (SS) is also shown. (c) Long-profile of fjord bathymetry, located in (a). VE x 10. (d) Cross-profile of fjord bathymetry, located in (a). VE x 0. (e) Sub-bottom seismic reflection profile of fjord basin-fill, located in (a). VE x 10. Acquisition system Parasound. Frequency 4 kHz. (f) Enlarged swath-bathymetric data of inner Nordvestfjord, superimposed on Landsat imagery (note the icebergs up to about $1.5 \mathrm{~km}$ long), with fjord floor channels (confluence arrowed) and the terminus of DJG. (g) Oblique photograph of Nordvestfjord showing steep fjord walls and icebergs; view location and direction shown by red arrow in (a). 


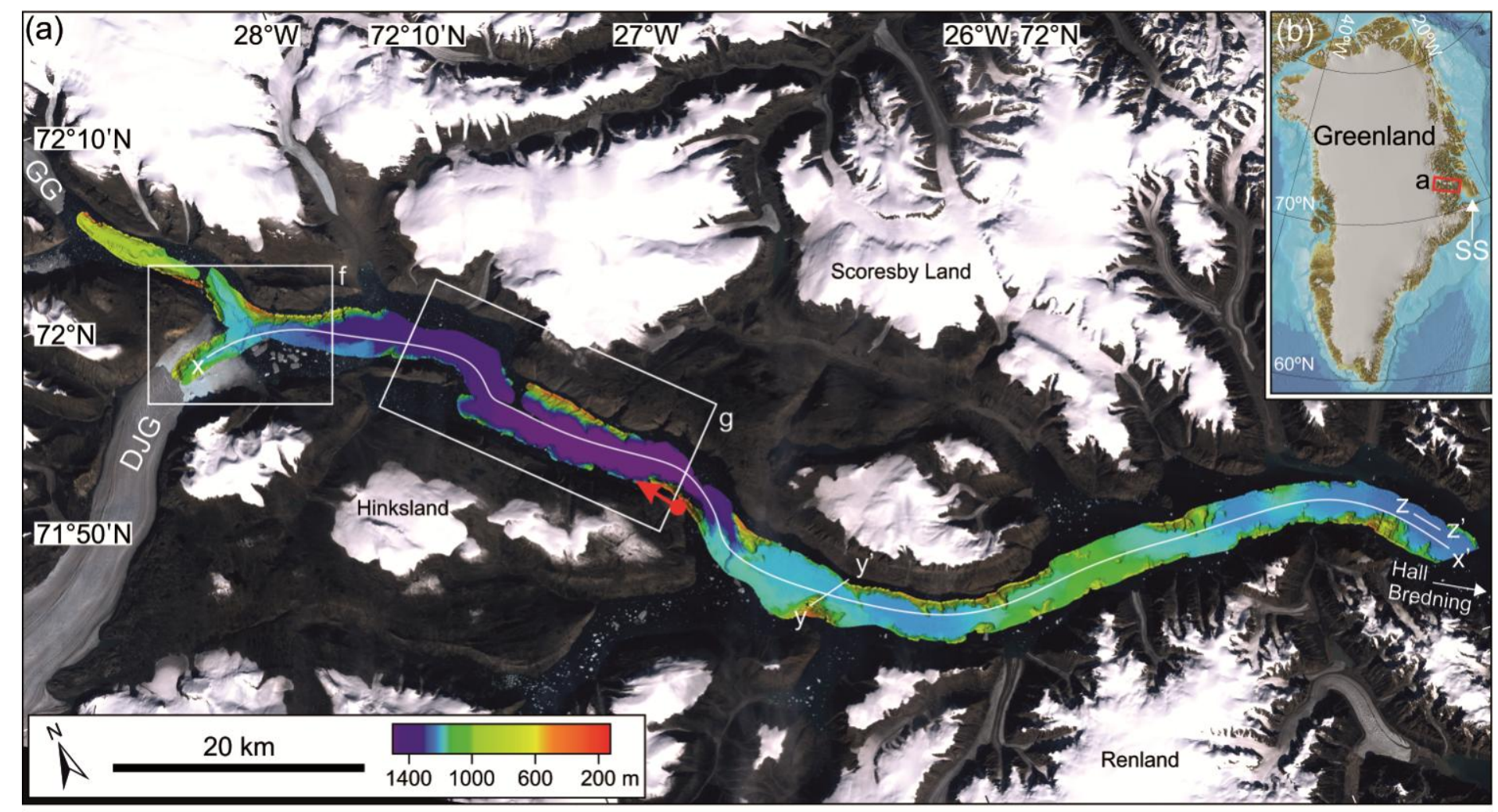

(c)
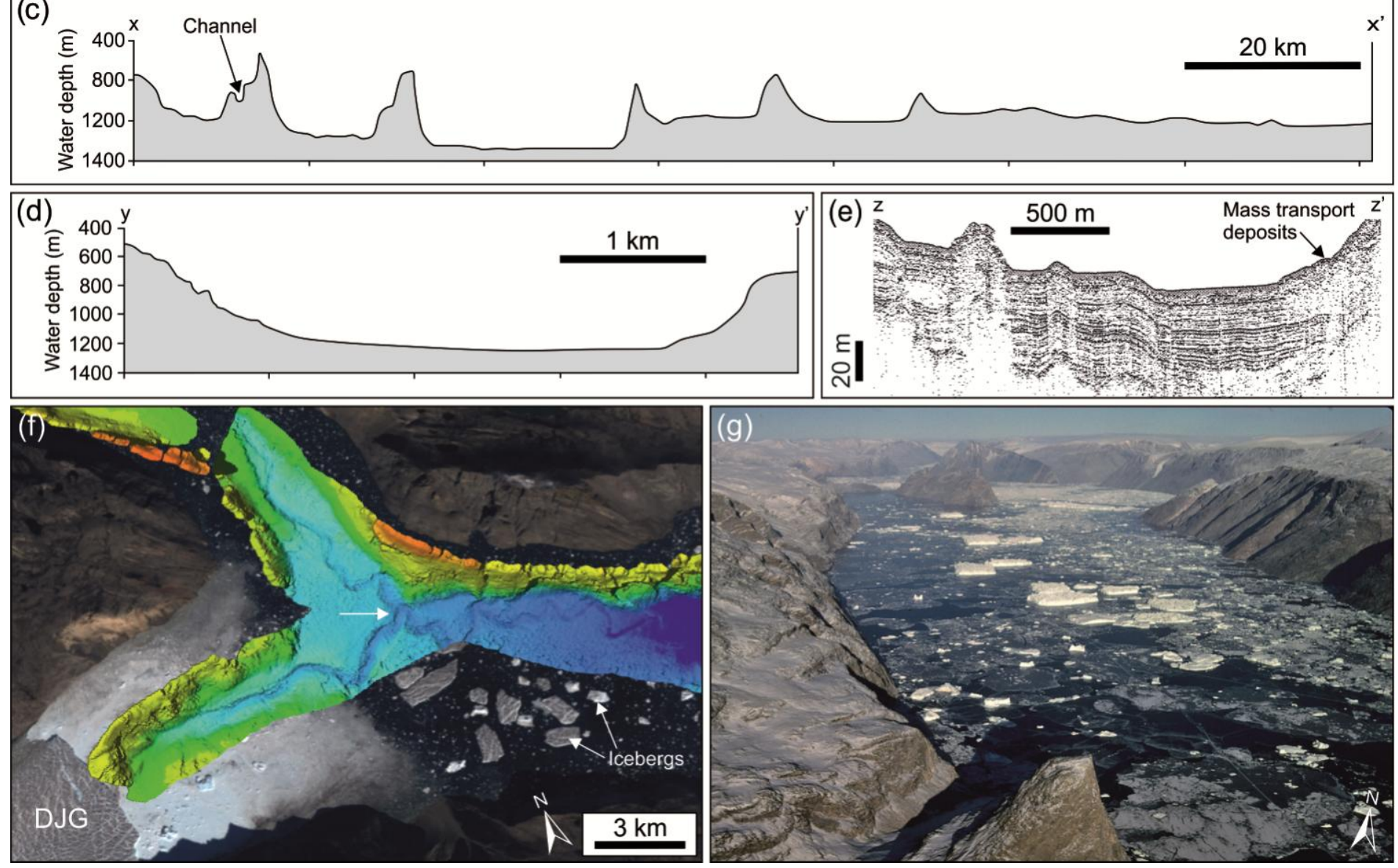